\title{
Waste Tank Vapor Project: Tank Vapor Database Development
}

\author{
P. R. Seesing \\ M. B. Birn \\ K. L. Manke
}

September 1994

Prepared for the U.S. Department of Energy

under Contract DE-AC06-76RLO 1830

Pacific Northwest Laboratory

Operated for the U.S. Department of Energy

by Battelle Memorial Institute 


\title{
DISCLAIMER
}

This report was prepared as an account of work sponsored by an agency of the United States Government. Neither the United States Government nor any agency thereof, nor Battelle Memorial Institute, nor any of their employees, makes any warranty, expressed or implied, or assumes any legal liability or responsibility for the accuracy, completeness, or usefulness of any information, apparatus, product, or process disclosed, or represents that its use would not infringe privately owned rights. Reference herein to any specific commercial product, process, or service by trade name, trademark, manufacturer, or otherwise does not necessarily constitute or imply its endorsement, recommendation, or favoring by the United States Government or any agency thereof, or Battelle Memorial Institute. The views and opinions of authors expressed herein do not necessarily state or reflect those of the United States Government or any agency thereof.

\author{
PACIFIC NORTHWEST LABORATORY \\ operated by \\ BATTELLE MEMORIAL INSTITUTE \\ for the \\ UNITED STATES DEPARTMENT OF ENERGY \\ under Contract DE-ACO6-76RLO 1830
}

Printed in the United States of America

Available to DOE and DOE contractors from the

Office of Scientific and Technical Information, P.O. Box 62, Oak Ridge, TN 37831; prices available from (615) 576-8401. FTS 626-8401.

Available to the public from the National Technical Information Service, U.S. Department of Commerce, 5285 Port Royal Rd., Springfield, VA 22161. 


\section{DISCLAIMER}

Portions of this document may be illegible in electronic image products. Images are produced from the best available original document. 
Waste Tank Vapor Project:

Tank Vapor Database Development

P. R. Seesing

M. B. Birn

K. L. Manke

September 1994

Prepared for

the U.S. Department of Energy

under Contract DE-AC06-76RLO 1830

Pacific Northwest Laboratory

Richland, Washington 99352

\section{MASTER}




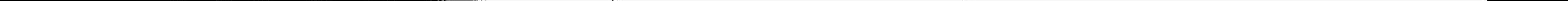




\section{Summary}

The objective of the Tank Vapor Database (TVD) Development task in FY 1994 was to create a database to store, retrieve, and analyze data collected from the vapor phase of Hanford waste tanks. The data needed to be accessible over the Hanford Local Area Network to users at both Westinghouse Hanford Company (WHC) and Pacific Northwest Laboratory (PNL). The data were restricted to results published in cleared reports from the laboratories analyzing vapor samples. Emphasis was placed on ease of access and flexibility of data formatting and reporting mechanisms.

Because of time and budget constraints, a Rapid Application Development strategy was adopted by the database development team. Meetings were held with Jerry Osborne and Jim Huckaby from WHC to build a conceptual model of the ultimate scope and desired uses of the database. Also, a working list of functional requirements was developed. The focus for FY 1994 was creating the relational database that would provide the information necessary for some of the long-term capabilities envisioned in the conceptual model. A milestone was established to make this database available by September 30, 1994.

An extensive data modeling exercise was conducted to determine the scope of information contained in the database. WHC and PNL scientists and managers participated in the modeling sessions. During the sessions, a broad data model and dictionary were developed. These were later simplified into a final data model and dictionary for the first release of TVD. The models were reviewed by staff who maintain the Tank Characterization Database and the Tank Waste Information Network System for compatibility with the technical and informational features of these systems. In the long term, the TVD will retrieve data from and share data with both of these systems.

A SUN ${ }^{\star}$ Sparcstation 1000 was procured as the database file server. A multi-user relational database management system, Sybase ${ }^{\oplus}$, was chosen to provide the basic data storage and retrieval capabilities. Two packages were chosen for the user interface to the database: DataPrism ${ }^{\oplus}$ and Business Objects $^{\text {Th }}$. DataPrism was chosen for its ability to be used without further customization with databases on the server and prototype databases developed on an IBM ${ }^{\star}$ personal computer. Business Objects was chosen for its customization features that simplify the interface with the database structures. Users will be able to use the interface that they find most friendly.

A prototype database was constructed to provide the Waste Tank Vapor Project's Toxicology task with summarized and detailed information presented at Vapor Conference 4 by WHC, PNL, Oak Ridge National Laboratory, and Oregon Graduate Institute. The prototype was used to develop a list of reported compounds, and the range of values for compounds reported by the analytical laboratories using different sample containers and analysis methodologies. The prototype allowed a panel of toxicology experts to identify carcinogens and compounds whose concentrations were within the reach of regulatory limits. 
The database and user documentation for Release 1 of the TVD were made available for general access in September 1994, meeting the formal milestone. The amount of data in the database was limited because of the small number of published reports available at that time. In 1995, plans call for the database to continue to expand with information on up to 60 tanks as the results are published, and with supplemental information about toxicology and meteorological conditions. Other features envisioned in the conceptual model will be developed as user interest and funding permit. 


\section{Acknowledgments}

No project happens in a vacuum. We, the authors of this report, would like to take this opportunity to thank those who helped make it possible:

- Steve Goheen for his support

- Jerry Osborne and Jim Huckaby for their vision and assistance

- Mike Story for his support in the early stages

- John Fruchter for his continued faith

- Tank Waste Information Network System (TWINS) and Tank Characterization Database staff for making comments and discussing them with us (especially Kris Cook, Jim Brown, Desiree Johnson, and Bruce Kissinger)

- TWINS staff for their technical support, loan of hardware, and continued assistance

- Mike Sherrill for his assistance with Business Objects

- Scientists and technicians who took the time to explain what data they wanted

- Bob Bryce, Rich Barchet, and Pat Hays, for helping to make this team possible. 


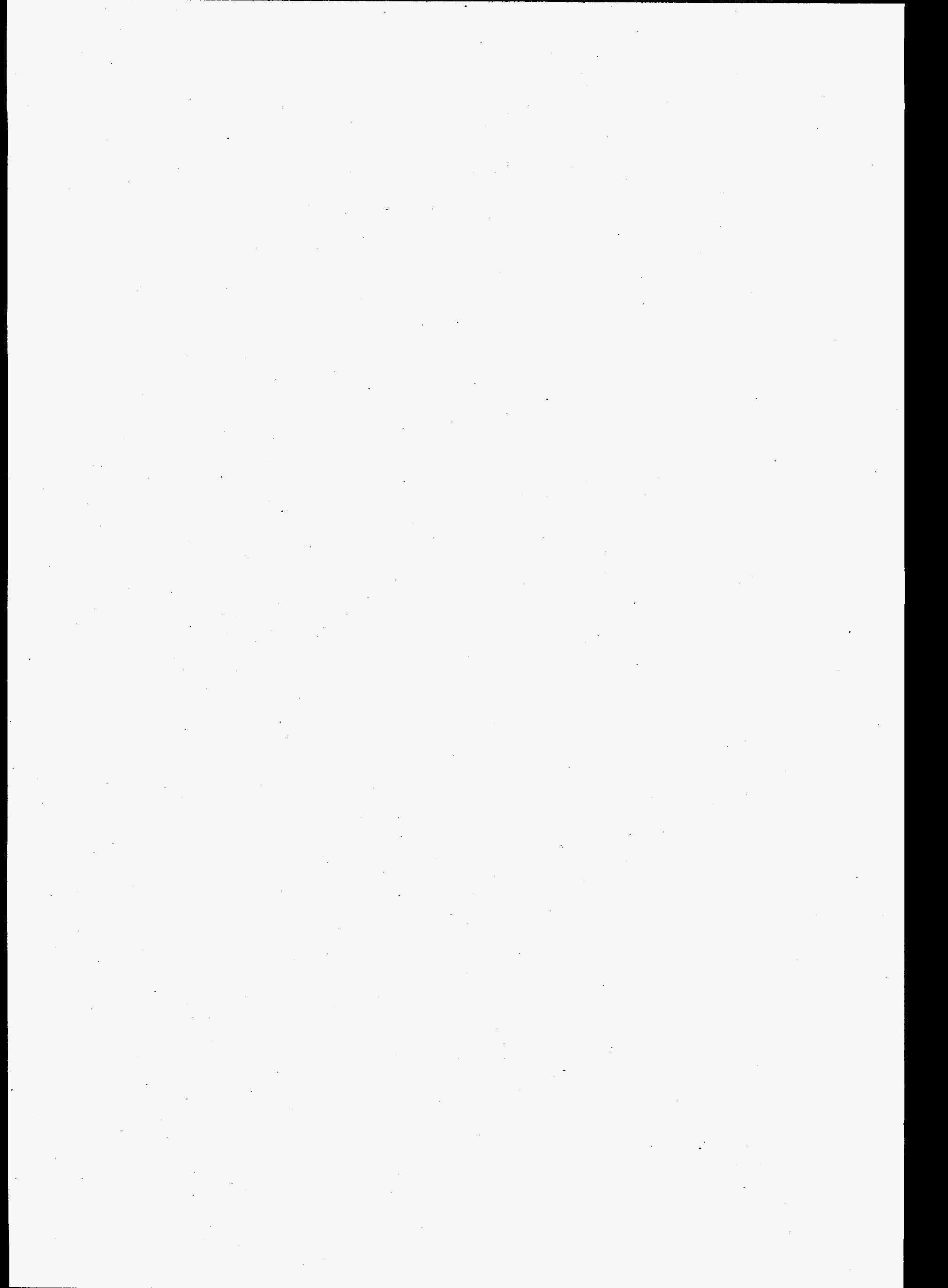




\section{Contents}

Summary $\ldots \ldots \ldots \ldots \ldots \ldots \ldots \ldots \ldots \ldots \ldots \ldots \ldots \ldots \ldots \ldots \ldots \ldots$ iii

Aknowledgments $\ldots \ldots \ldots \ldots \ldots \ldots \ldots \ldots \ldots \ldots \ldots \ldots \ldots \ldots \ldots \ldots$

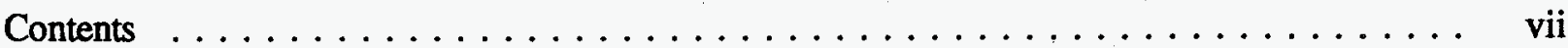

Trademarks Used $\ldots \ldots \ldots \ldots \ldots \ldots \ldots \ldots \ldots \ldots \ldots \ldots \ldots \ldots$

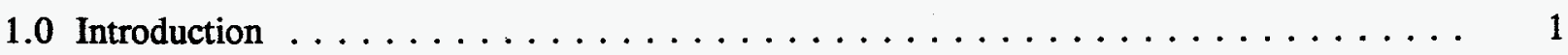

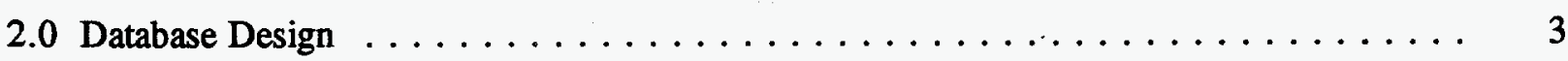

3.0 Database Hardware and Software Acquisition $\ldots \ldots \ldots \ldots \ldots \ldots \ldots$

4.0 Prototype Creation $\ldots \ldots \ldots \ldots \ldots \ldots \ldots \ldots \ldots \ldots \ldots \ldots \ldots$

5.0 Release 1.0 Implementation $\ldots \ldots \ldots \ldots \ldots \ldots \ldots \ldots \ldots$

Appendix A - Tank Vapor Database Conceptual Model . . . . . . . . . . . . . . . A.1

Appendix B - Data Model $2.0 \ldots \ldots \ldots \ldots \ldots \ldots \ldots \ldots \ldots \ldots \ldots$

Appendix C - Model $3.3-$ TVD Release $1 \ldots \ldots \ldots \ldots \ldots \ldots \ldots$

Appendix D - Data Dictionary - TVD Release $1 \ldots \ldots \ldots \ldots \ldots \ldots$

Appendix E - Component Hardware List for Tank Vapor Database Server . . . . . . . . . . E.1

\section{Trademarks Used}

- SUN is a registered trademark of SUN Microsystems, Mountain View, California.

- Sybase and Omni-SQL are registered trademarks of Sybase, Inc., Emeryville, California.

- DataPrism is a registered trademark of Brio Technology, Inc., Mountain View, California.

Business Objects is a trademark of Business Objects, Menlo Park, California.

- IBM is a registered trademark of International Business Machines, Armonk, New York.

- Oracle is a registered trademark of Oracle Corporation, Redwood City, California.

- Macintosh is a registered trademark of Apple Computer, Inc., Cupertino, California.

- Microsoft is a registered trademark of Microsoft Corporation, Redmond, Washington.

${ }^{\mathrm{m}}$ Windows is a trademark of Microsoft Corporation, Redmond, Washington.

All other product names may be registered trademarks of their respective companies. 


\subsection{Introduction}

Westinghouse Hanford Company's (WHC) Health and Safety organization has sponsored Pacific Northwest Laboratory's (PNL) (a) Tank Vapor Program. The program began in 1992 by studying means of sampling and analyzing vapors from the headspace of Hanford's single- and double-shell tanks. In 1993, the program grew to include offsite personnel from Oregon Graduate Institute (OGI), Oak Ridge National Laboratory (ORNL), and Sandia National Laboratory (SNL) in the analysis phase as well as PNL's Analytical Laboratories staff. The information generated from these laboratories will be used by Hanford managers, chemists, and toxicologists to make key safety decisions and to aid ongoing study relating to tank characterization and remediation activities. The Tank Vapor Program is a multi-year effort, including extensive vapor sampling of every single- and double-shell waste tank.

In 1993, the WHC manager of the program, Jerry Osborne, requested that PNL develop extensive database capabilities to support the work being done by the Tank Vapor Program participants. The long-term goals for the Tank Vapor Database (TVD) were

- electronic storage of data and images

- data compatibility and comparability with existing characterization databases

- data availability to scientists, managers, and stakeholders

- flexibility for synthesis, analysis, and hypothesis

- data to drive tank behavioral models

- rapid notification of safety issues determined from the data.

In response to WHC's expressed desire to have a working system implemented by the end of FY 1994, a Rapid Application Development (RAD) methodology was developed and implemented. The goal of the RAD methodology was to create working prototypes of the system as soon as possible for customer review and comment. The final product is the result of the refinement of successive prototypes. One of the strengths of this approach is that it recognizes that requirements may change over the course of the development and that such changes are made in a controlled way.

Being able to interact with the prototypes, a user is better able to visualize the completed system sooner in the development cycle. The inevitable flurry of system change requests that follow Release 1 in traditional software development are identified during the development phase in the RAD method. The method also ensures that extensive hands-on testing of the product is performed, and that human factors and preferences are identified early in the development.

(a) Operated by Battelle Memorial Institute for the U.S. Department of Energy under Contract DE-AC06-76RLO 1830. 
From November to December 1993, a needs analysis was conducted with Jerry Osborne, Jim Huckaby (WHC), and the PNL task leaders for the Waste Tank Vapor Project, resulting in an initial set of user requirements. These requirements were summarized in a conceptual model that provides the high-level view of the desired system's capabilities. This model is presented in Appendix A.

The WHC program manager was very explicit in his desire to have the information be widely accessible over the Hanford Local Area Network (HLAN), and have a flexible and user-friendly interface. Existing PNL guidelines and configurations for client-server database systems and platforms were used to build the system. Another critical feature of the database from the customer's perspective was that it would contain only cleared results (not interim results or draft findings) and that all results would be identifiable with their source document.

Time and budget constraints in 1994 prevented the simultaneous development of all the features of the conceptual model. The decision was made to focus FY 1994 activities on the development of a relational database that stored analytical results. A milestone was established to make this database available using HLAN by September 30, 1994.

An extensive data modeling exercise was undertaken. Prototypes were created and tested on IBM ${ }^{\star}$ personal computers to fine-tune various sections of the data model. The core tables of the TVD were made available using HLAN in September 1994, meeting the formal milestone. The amount of data in the database was limited because of the small number of cleared reports available at that time.

In FY 1995, the database will continue to expand with information on up to 60 tanks as the results are cleared. Supplemental information about toxicology and meteorological conditions will be added. Other features envisioned in the conceptual model will be developed as user interest and funding permit. 


\subsection{Database Design}

The database design process began in January 1994, with extensive interviews of the Waste Tank Vapor Project task leaders and analytical chemists. The goal was to identify a broad spectrum of information that would be useful in adding context to the quantitative results expected from vapor sample analysis. This information included sample event data, meteorological data, toxicology and general chemical data, quality assurance, and organization data.

Relational databases organize data as a set of tables, each entry in a table containing one or more related pieces of information. The two traditional tools for documenting the layout of this kind of database are data models (also known as Entity-Relationship diagrams) and the data dictionary. A data model was created to organize the information obtained during the individual interviews. This model represents a universe of information that the scientific and management community felt would be useful in understanding the results obtained by vapor analysis. This model is presented in Appendix B. A data dictionary was created to accompany the model.

The data model was presented at a meeting of the WHC and PNL managers and scientists involved. This meeting was a starting point for numerous discussions about the actual amount and type of information that would be stored in the database. The data model was revised to reflect the higher level of information that WHC wanted. The data model that was created at the conclusion of the discussions is shown in Appendix C. The data dictionary was also revised; it is presented in Appendix D.

Computer scientists who maintain the Tank Characterization Database (TCD) and the Tank Waste Information Network System (TWINS) also reviewed the data model and dictionary. This was important because the long-term strategy for the TVD involves exchanging data with TCD rather than storing the data a second time in the TVD. Also, the TVD will be a component of TWINS, which will provide a convenient mechanism for the wide accessibility of the data envisioned by Jerry Osborne. Compatibility and comparability with these two systems was ensured by these design reviews. 


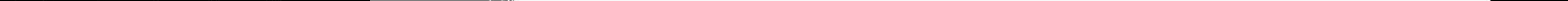




\subsection{Database Hardware and Software Acquisition}

As is appropriate to the RAD method, the decisions on hardware and software were driven more by functional criteria than by a formal market survey.

The choice of the SUN ${ }^{\circ}$ Sparcstation 1000 as the database server was driven by the fact that it is the platform of choice for PNL system development projects. There is ample expertise in the operation and management of this machine in PNL's Information Systems and Services organization, and the platform is identical to that used for the TWINS database server (minimizing connectivity, compatibility, and support issues). The technical merits of this platform are discussed in the Automated Data Processing Acquisition and Implementation Plan presented in April 1994, as part of the procurement of this equipment, and available upon request. The component hardware list for the database server is presented in Appendix E.

The choice of Sybase ${ }^{\circledast}$ as the underlying database management system (DBMS) was driven by similar considerations. This product is used by TWINS and is preferred by PNL computer scientists because of its faster performance in data retrieval than the Oracle ${ }^{\otimes}$ DBMS used by TCD. A product known as Omni-SQL Gateway will be procured in FY 1995 to provide connectivity between TVD and TCD. This product bridges the technical differences between the two underlying DBMS.

Almost 35 user interface software packages, also known as client-server software, were examined. Two packages were chosen for TVD development: DataPrism ${ }^{\oplus}$ and Business Objects ${ }^{\mathrm{Tm}}$. DataPrism was chosen for its ability to be used without further customization with databases on the server and prototype databases developed on an IBM personal computer, and for its identical look and feel on Macintosh ${ }^{\circ}$ and IBM personal computers. Business Objects was chosen for its customization features that simplify the interface with the database structures, and because of an existing Site license that makes it available at no additional cost to PNL users. 



\subsection{Prototype Creation}

Prototypes allow developers and users to experiment with data storage and retrieval strategies in an environment where the system can be quickly modified. Also, prototypes allow development to begin in advance of the arrival of procured hardware and software for the formal database (which in this case took 6 months). Even though they are throw-away products, prototypes prove the workability and effectiveness of design options.

In April 1994, a prototype database was constructed on an IBM personal computer to provide the Waste Tank Vapor Project's Toxicology task with summarized and detailed information about sample job 6B as presented at Vapor Conference 4 by WHC, PNL, ORNL, and OGI. The prototype was used to develop a list of 160 compounds and the range of values reported for those compounds by the laboratories. Because each laboratory used different sample containers and analysis methodologies, this provided a good indication of consistency of findings. It allowed a panel of toxicology experts to identify carcinogens and compounds whose concentrations were within reach of regulatory limits.

From a database development perspective, the prototype served as a test of the user interface software as well as a chance to check the congruence of the data model with data as actually reported. It allowed the developers to experiment with various ways of representing the data, and to observe first-hand one of the practical uses of the data - toxicological review. The feedback gained from this process led to the establishment of the table of regulatory limits for the database. The exercise also identified the necessity of creating a chemical identification table that had all of the compounds identified. 


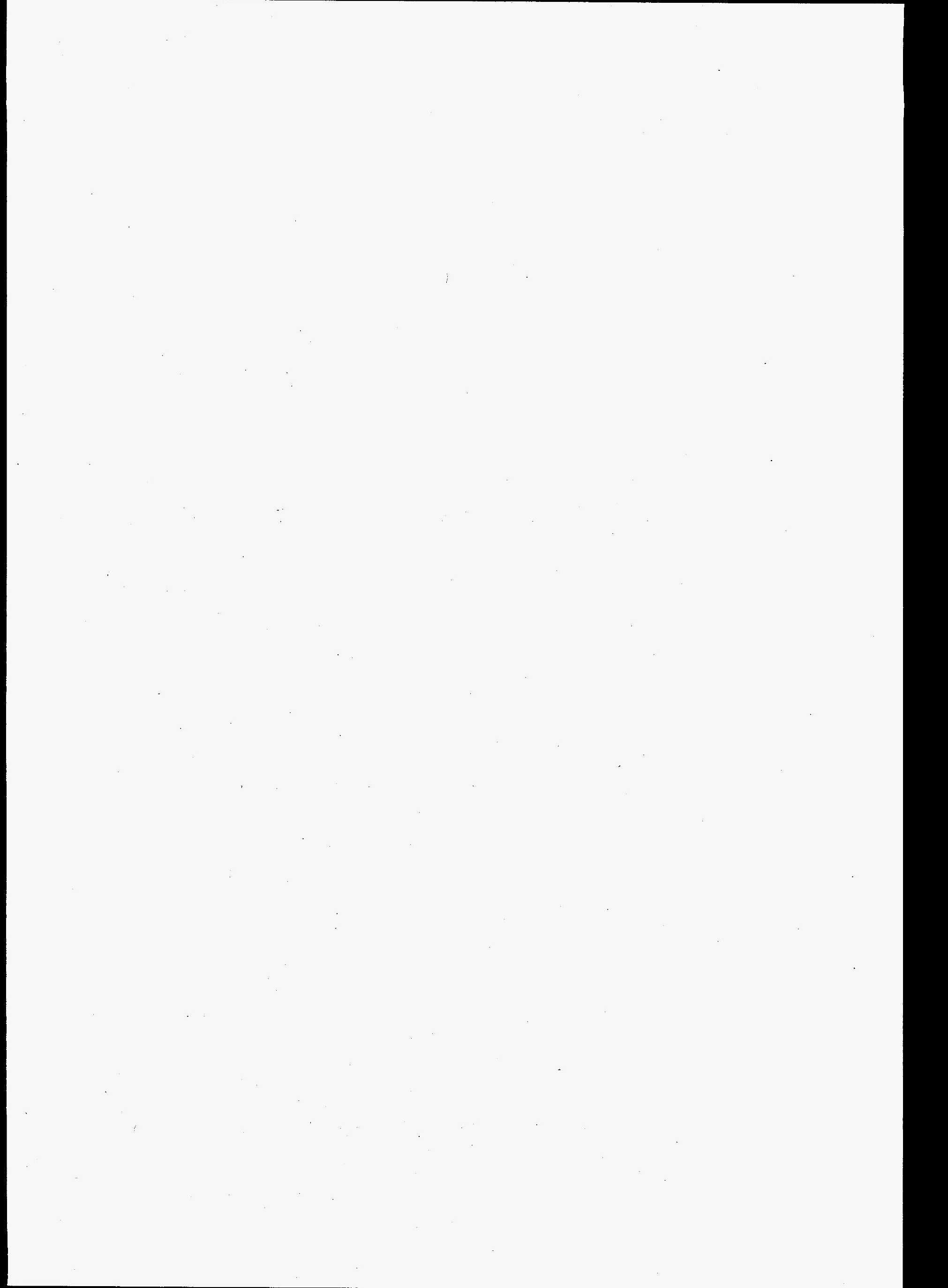




\subsection{Release 1.0 Implementation}

The TVD users will have read-only access to the database; the TVD data administrators will validate and update the database. All data are assembled on an IBM personal computer and validated before insertion into the TVD. This may occur in two ways. Data may be identified by reading the cleared report and entering the data by hand using software created for that purpose. Alternatively, data may be received in electronic format from the laboratory and then converted electronically to the TVD format. In both cases, data are cross-checked with the paper copy of the cleared report to ensure accuracy.

To establish a connection to the TVD, please contact any of the authors. To be able to use TVD, you must have the following:

- $80386 \mathrm{SX}$ or better microcomputer

- Microsoft Windows $^{\text {Ti }} 3.1$ or better

- a Transmission Control Protocol/Internet Protocol (TCP/IP) connection over a local or wide area network

- a copy of the user interface software and associated software libraries

- a user-id and password from PNL.

Instructions for running the user interface software may be found in the TVD User's Guide, available separately from the authors. The user's guide contains step-by-step instructions for logging in and out of the system, creating and running queries against the database, and formatting the query results using the interface's report writing capabilities.

As of September 1994, only parts of the data for tank 241-C-103 are loaded, because this is the only data that has been cleared. The remainder of the data for this tank, and data for the other tanks, will be loaded as it is cleared by WHC or the analytical laboratory.

Supplemental data tables for general chemical information, meteorology, and toxicology will continue to be loaded and enhanced (funding permitting) as the information is identified. The database contents as well as its design have been driven by user comments. User suggestions are expected to increase as experience with the database grows. The architecture of the database has the flexibility to change data structures and incorporate new areas of information as needed. The final decision concerning the inclusion or exclusion of any data from the database will be made by the WHC program manager. 
Appendix A

Tank Vapor Database Conceptual Model 


\section{Tank Vapor Database System Conceptual Model}




Appendix B

Data Model 2.0 


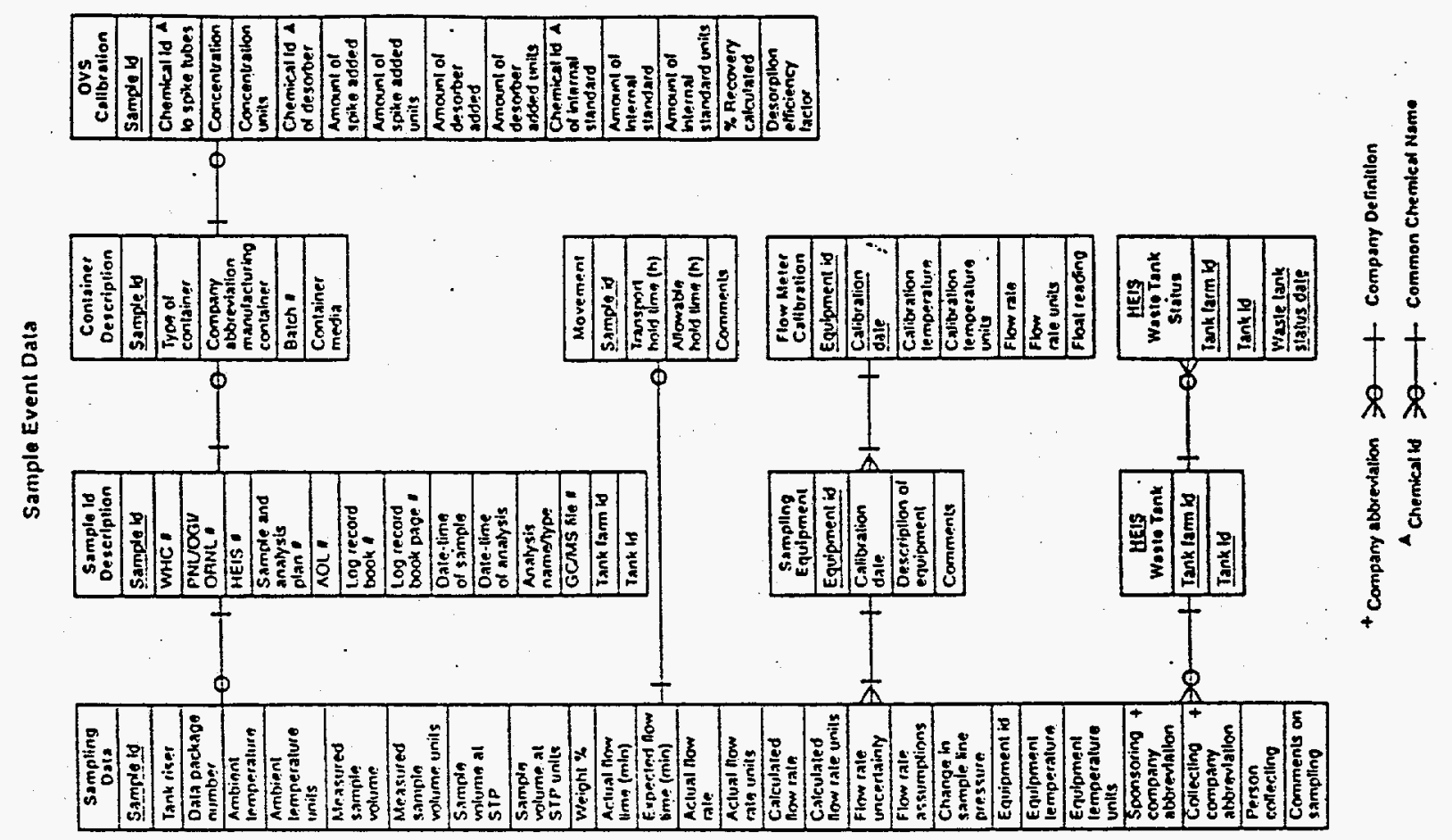

$\frac{5}{5}$
$\frac{5}{0}$
$\frac{5}{0}$
$\frac{0}{0}$
$\frac{0}{0}$
$\frac{0}{2}$

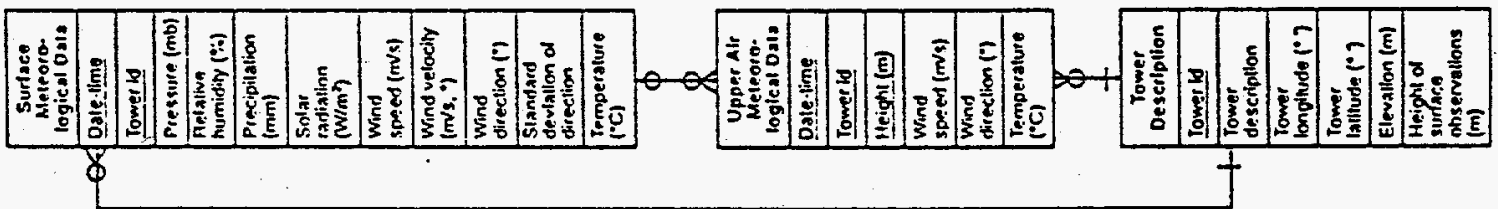
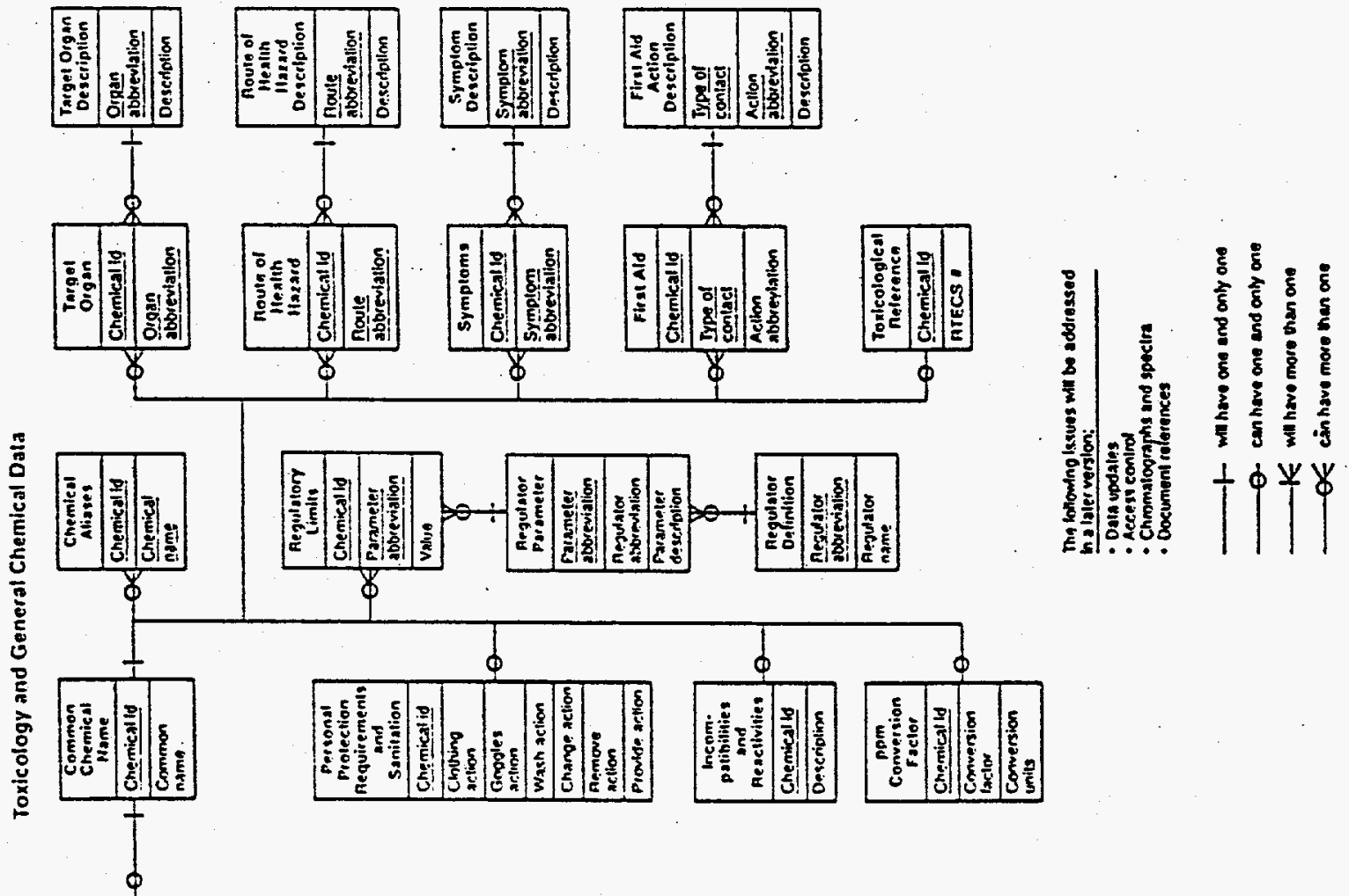

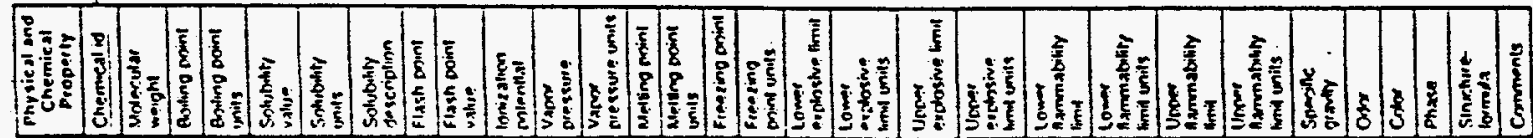




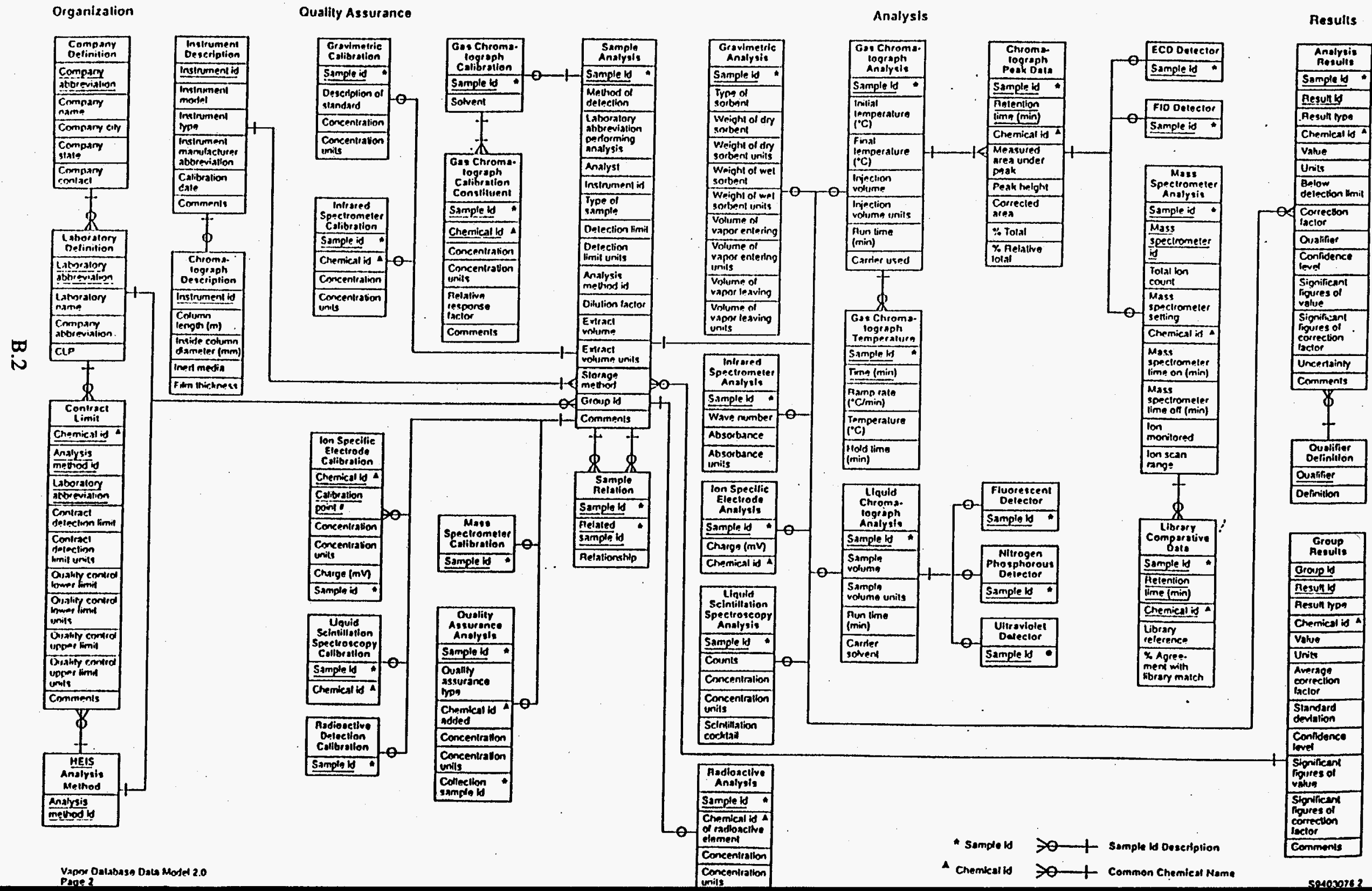


Appendix C

Data Model 3.3 - TVD Release 1 


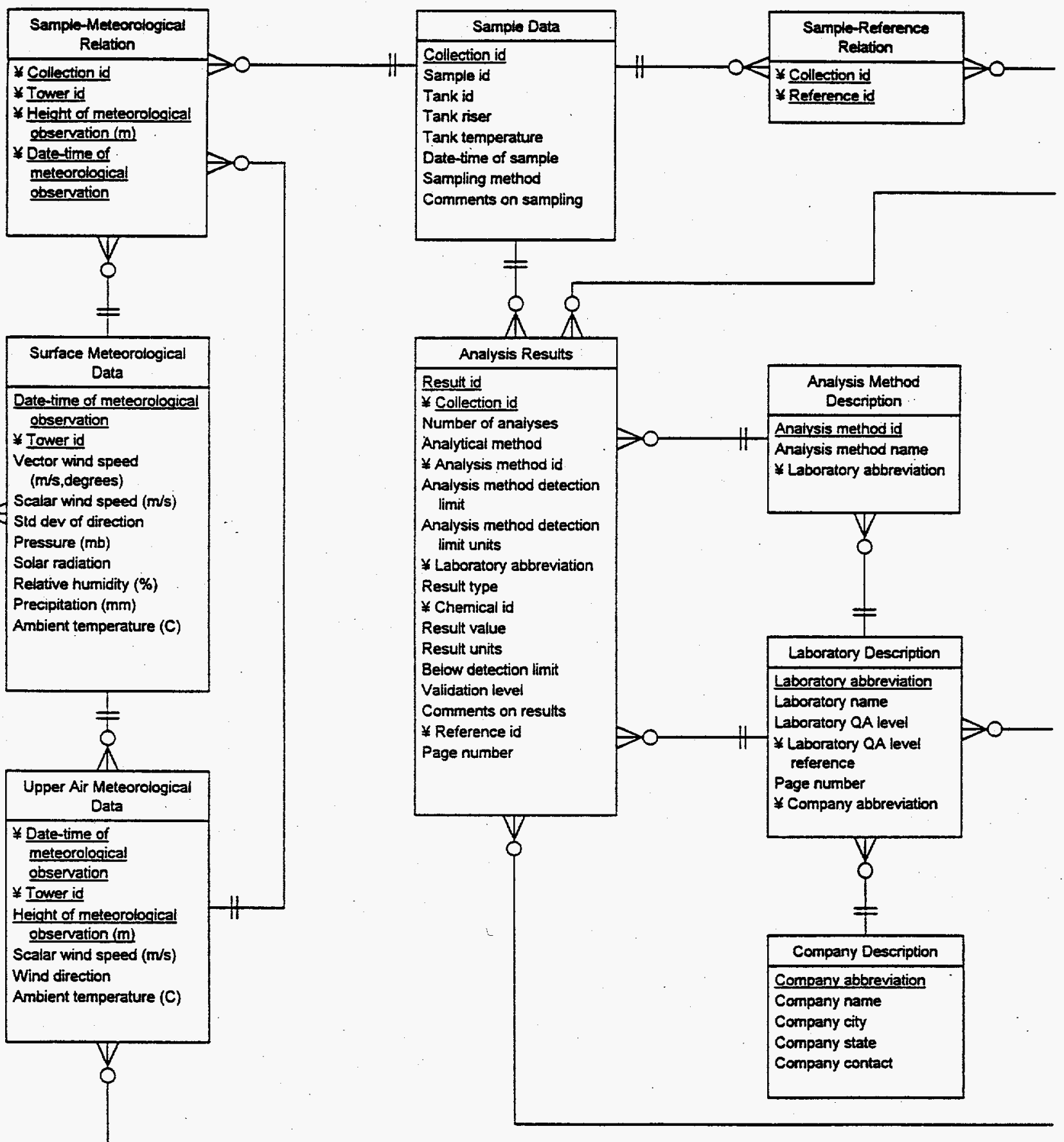

Vapor Database Data Model 3.3 09/09/94

C. 1 


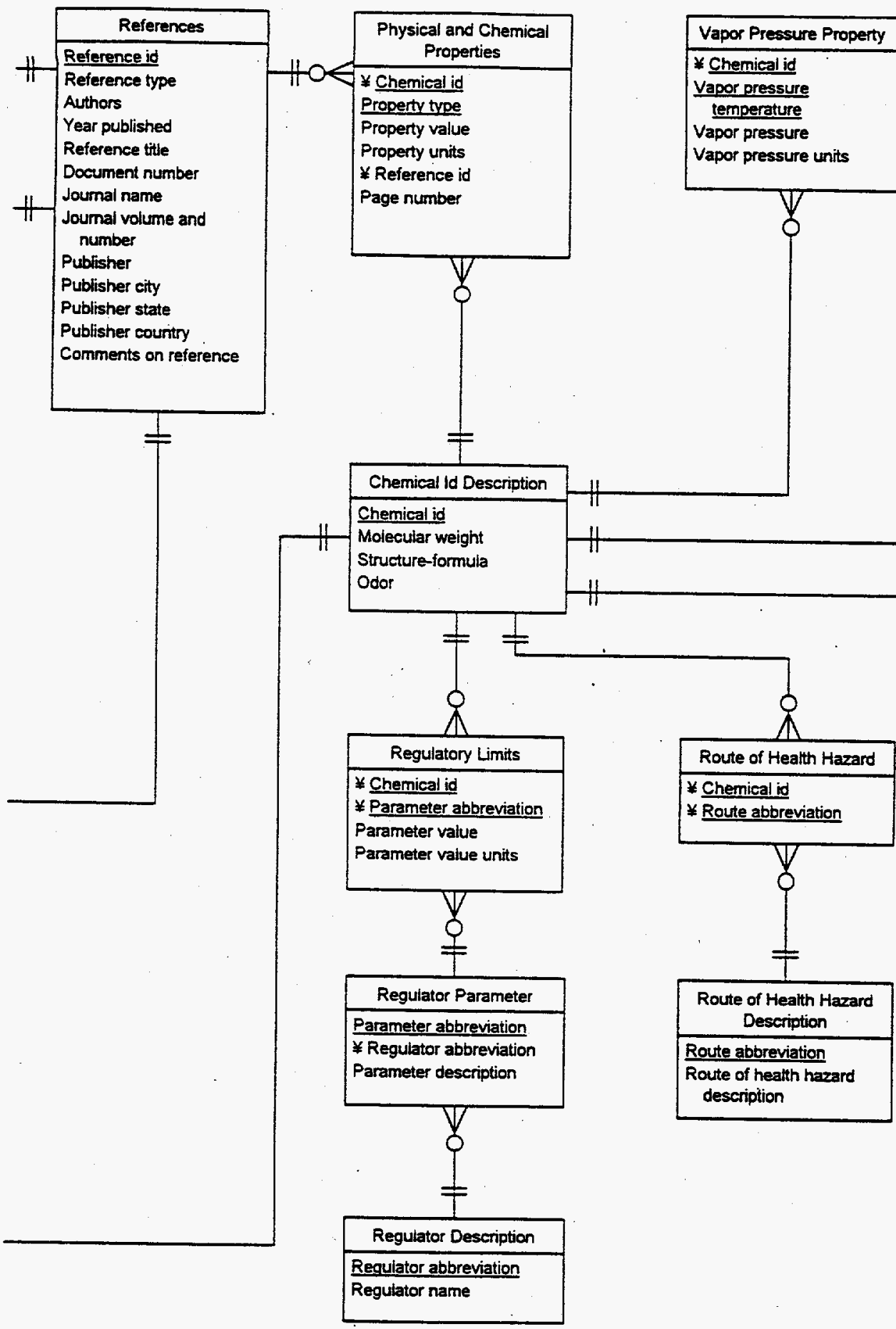

Chemical Name Description

* Chemical id

Chemical name

Frequency used
Property units

erence id

Publisher state

Publisher country

Comments on reference

Molecular weight

Structure-formula

Chemical is

Parameter abbreviation

arameter value 


\section{Appendix D}

\section{Data Dictionary - TVD Release 1}




\section{Tank Vapor Chemistry Data Dictionary}

\begin{tabular}{|c|c|c|c|c|c|c|c|}
\hline Entity Name & Description & Examples & Table Name & Key Field? & Can be Nuli? & Type/Length & \\
\hline \multirow[t]{2}{*}{ Ambient temperature } & $\begin{array}{l}\text { Temperature of the air around a } \\
\text { meteorological tower (units are }{ }^{\circ} \mathrm{C} \text { ). The } \\
\text { ambient temperature is reported as a } 15- \\
\text { minute average }\end{array}$ & $10^{\circ} \mathrm{C}$ & $\begin{array}{l}\text { Surface Meteorological } \\
\text { Data }\end{array}$ & No & Yes & float & \\
\hline & & & $\begin{array}{l}\text { Upper Air } \\
\text { Meteorological Data }\end{array}$ & No & Yes & float & \\
\hline $\begin{array}{l}\text { Analysis method detection } \\
\text { limit }\end{array}$ & $\begin{array}{l}\text { Lowest amount a laboratory instrument } \\
\text { can reliably detect }\end{array}$ & 10.9 & Analysis Results & No & Yes & float & \\
\hline $\begin{array}{l}\text { Analysis method detection } \\
\text { limit units }\end{array}$ & $\begin{array}{l}\text { Units for the lowest amount a laboratory } \\
\text { instrument can reliably detect }\end{array}$ & $\mathrm{mg} / \mathrm{L}$ & Analysis Results & No & Yes & char & 10 \\
\hline \multirow[t]{2}{*}{ Analysis method id } & $\begin{array}{l}\text { Code that identifies the methods, } \\
\text { procedures, and/or protocols that } \\
\text { describe how the results were obtained } \\
\text { from a sample (a sample is defined as a } \\
\text { discrete quantity of material collected for } \\
\text { analysis) }\end{array}$ & 54836 & $\begin{array}{l}\text { Analysis Method } \\
\text { Description }\end{array}$ & Yes & No & char & 15 \\
\hline & & & Analysis Results & No & Yes & char & 15 \\
\hline Analysis method name & $\begin{array}{l}\text { Description of the analysis method id; } \\
\text { this includes the name of the methods, } \\
\text { procedures, and/or protocols used to } \\
\text { obtain the results }\end{array}$ & EPA SW-846, Thallium & $\begin{array}{l}\text { Analysis Method } \\
\text { Description }\end{array}$ & No & No & varchar & 30 \\
\hline Analytical method & $\begin{array}{l}\text { Primary instrumentation used to analyze } \\
\text { a sample (a sample is defined as a } \\
\text { discrete quantity of material collected for } \\
\text { analysis). If the sample does not involve } \\
\text { a specific instrument (for example, } \\
\text { gravimetric analysis), then a general } \\
\text { description is reported }\end{array}$ & $\begin{array}{l}\text { GCMS } \\
\text { lon chromatograph } \\
\text { Gravimetric }\end{array}$ & Analysis Results & No & Yes & varchar & 50 \\
\hline
\end{tabular}




\begin{tabular}{|c|c|c|c|c|c|c|c|}
\hline Entity Name & Description. & Examples & Table Name & Key Field? & Can be Null? & Type/Length & \\
\hline Authors & $\begin{array}{l}\text { People listed (by first and middle initial } \\
\text { and last name) as writers. If authors are } \\
\text { not listed, then the name of the company } \\
\text { that produced the reference is reported. } \\
\text { If a company is not listed, then the word } \\
\text { "Anonymous" is reported }\end{array}$ & $\begin{array}{l}\text { K. L. Manke, M. B. Birn, P. R. } \\
\text { Seesing } \\
\text { EPA } \\
\text { Anonymous }\end{array}$ & References & No & No & varchar & 255 \\
\hline Below detection limit & $\begin{array}{l}\text { If a result was not reported because the } \\
\text { value was below the detection limit of the } \\
\text { instrumentation, then a } Y \text { is reported. If a } \\
\text { result was above the the detection limit of } \\
\text { the instrumentation, then a } N \text { is reported }\end{array}$ & $\begin{array}{l}Y \\
N\end{array}$ & Analysis Results & No & Yes & char & 1 \\
\hline \multirow[t]{5}{*}{ Chemical id } & $\begin{array}{l}\text { Chemical Abstract Services (CAS) } \\
\text { number or appropriate code that uniquely } \\
\text { identifies a chemical (a chemical is } \\
\text { defined as an element or a compound, } \\
\text { which includes radionuclides) }\end{array}$ & $\begin{array}{l}67-66-3 \\
109-79-5\end{array}$ & Analysis Results & No & No & char & 15 \\
\hline & & & Chemical Id Description & Yes & No & char & 15 \\
\hline & & & $\begin{array}{l}\text { Chemical Name } \\
\text { Description }\end{array}$ & Yes & No & char & 15 \\
\hline & & & $\begin{array}{l}\text { Physical and Chemical } \\
\text { Properties }\end{array}$ & Yes & No & char & 15 \\
\hline & & & Regulatory Limits & Yes & No & char & 15 \\
\hline & & & Route of Health Hazard & Yes & No & char & 15 \\
\hline & & & Symptoms & Yes & No & char & 15 \\
\hline & & & $\begin{array}{l}\text { Vapor Pressure } \\
\text { Property }\end{array}$ & Yes & No & char & 15 \\
\hline Chemical name & $\begin{array}{l}\text { Name of a chemical (a chemical is } \\
\text { defined as an element or a compound, } \\
\text { which includes radionuclides) }\end{array}$ & $\begin{array}{l}\text { Hexane } \\
\text { Hexyl hydride }\end{array}$ & $\begin{array}{l}\text { Chemical Name } \\
\text { Description }\end{array}$ & Yes & No & varchar & 240 \\
\hline
\end{tabular}

20-Sep-94 
ste record unique. This code

is internal to the database and should not

be used for tracking purposes

Comments on reference

Comments on results

Comments on sampling

Company abbreviation
Name of city where the company

responsible for the overall management

of the laboratory is located (the onsite

location is reported - not the

headquarters location, unless they are

the same)

$\begin{array}{lllll}\text { Sample Data } & \text { Yes } & \text { No } & \text { char } & 12 \\ \begin{array}{l}\text { Sample-Meteorological } \\ \text { Relation }\end{array} & \text { Yes } & \text { No } & \text { char } & 12 \\ \text { Sample-Reference } & \text { Yes } & \text { No } & \text { char } & 12\end{array}$

References

No

Yes

text Kline's Vapor Studies in

January 1994

Corrected for possible

Analysis Results

No

Yes

text

painting in adjacent laboratory

during trap analysis.

Valve connection was

contaminated. The sampling

Sample Data

No

Yes

text

amount is in question.

collected for analysis)

Acronym of the company responsible for WHC

PNL

Company Description

Yes

No

char

Laboratory Description

No

No

char

Richland

Company Description

No ext

t

varchar

30 


\begin{tabular}{|c|c|c|c|c|c|c|c|}
\hline Entity Name & Description & Examples & Table Name & Key Field? & Can be Null? & Type/Length & \\
\hline Company contact & $\begin{array}{l}\text { Telephone number including area code } \\
\text { of the main switchboard of the company } \\
\text { responsible for the overall management } \\
\text { of the laboratory (using this number is } \\
\text { the first step in contacting the company; } \\
\text { the switchboard operator should be able } \\
\text { to provide other numbers and information) }\end{array}$ & $\begin{array}{l}509-376-7411 \\
1-800-436-2437\end{array}$ & Company Description & No & Yes & char & 14 \\
\hline Company name & $\begin{array}{l}\text { Name of company responsible for the } \\
\text { overall management of the laboratory }\end{array}$ & $\begin{array}{l}\text { Westinghouse Hanford } \\
\text { Company }\end{array}$ & Company Description & No & No & varchar & 255 \\
\hline Company state & $\begin{array}{l}\text { Two-letter abbreviation of the state where } \\
\text { the company responsible for the overall } \\
\text { management of the laboratory is located } \\
\text { (the onsite location is reported -- not the } \\
\text { headquarters location, unless they are } \\
\text { the same). }\end{array}$ & WA & Company Description & No & Yes & char & 2 \\
\hline \multirow[t]{3}{*}{$\begin{array}{l}\text { Date-time of meteorological } \\
\text { observation }\end{array}$} & $\begin{array}{l}\text { Date and time the meteorological data } \\
\text { were reported at the meteorological tower }\end{array}$ & $11-11-199312: 56$ & $\begin{array}{l}\text { Sample-Meteorological } \\
\text { Relation }\end{array}$ & Yes & No & datetime & \\
\hline & . & & $\begin{array}{l}\text { Surface Meteorological } \\
\text { Data }\end{array}$ & Yes & No & datetime & \\
\hline & & & $\begin{array}{l}\text { Upper Air } \\
\text { Meteorological Data }\end{array}$ & Yes & No & datetime & \\
\hline Date-time of sample & $\begin{array}{l}\text { Date and time the sample was taken (a } \\
\text { sample is defined as a discrete quantity } \\
\text { of material collected for analysis) }\end{array}$ & 09-09-1993 11:44 & Sample Data & No & No & datetime & \\
\hline Document number & $\begin{array}{l}\text { Code assigned by government agencies } \\
\text { or government contractors to documents } \\
\text { and correspondence they publish; the } \\
\text { code is used for tracking purposes. This } \\
\text { code includes revision numbers. This } \\
\text { code does not include the UC category, } \\
\text { which is used by the Office of Scientific } \\
\text { and Technical Information }\end{array}$ & $\begin{array}{l}\text { WHC-EP-0474 Rev } 1 \\
\text { RL930008765 }\end{array}$ & References & No & Yes & varchar & 30 \\
\hline
\end{tabular}




\begin{tabular}{|c|c|c|c|c|c|c|c|}
\hline Entity Name & Description & Examples & Table Name & Key Field? & Can be Null? & Type/Length & \\
\hline $\begin{array}{l}\text { Elevation of meteorological } \\
\text { tower }\end{array}$ & $\begin{array}{l}\text { Height above sea level of the base of a } \\
\text { meteorological tower (units are meters) }\end{array}$ & $233 m$ & $\begin{array}{l}\text { Meteorological Tower } \\
\text { Description }\end{array}$ & No & Yes & int & \\
\hline Frequency used & $\begin{array}{l}\text { The standard name is the name } \\
\text { assigned to the Chemical Abstract } \\
\text { Services number. A synonym is any } \\
\text { other name associated with the chemical. }\end{array}$ & $\begin{array}{l}\text { Standard name } \\
\text { Synonym }\end{array}$ & $\begin{array}{l}\text { Chemical Name } \\
\text { Description }\end{array}$ & No & No & char & 15 \\
\hline \multirow[t]{2}{*}{$\begin{array}{l}\text { Height of meteorological } \\
\text { observation }\end{array}$} & $\begin{array}{l}\text { Vertical distance from the ground to } \\
\text { where the surface meteorological } \\
\text { measurement was taken (units are } \\
\text { meters) }\end{array}$ & $60 \mathrm{~m}$ & $\begin{array}{l}\text { Sample-Meteorological } \\
\text { Relation }\end{array}$ & Yes & No & int & \\
\hline & & & $\begin{array}{l}\text { Upper Air } \\
\text { Meteorological Data }\end{array}$ & Yes & No & int & \\
\hline $\begin{array}{l}\text { Height of surface } \\
\text { observations }\end{array}$ & $\begin{array}{l}\text { Vertical distance from the base of a } \\
\text { meteorological tower to the instruments } \\
\text { measuring surface meteorological } \\
\text { parameters were located (units are } \\
\text { meters) }\end{array}$ & $2 m$ & $\begin{array}{l}\text { Meteorological Tower } \\
\text { Description }\end{array}$ & No & Yes & int & \\
\hline Journal name & $\begin{array}{l}\text { Title of the journal. Subtitles are entered } \\
\text { after a colon }\end{array}$ & $\begin{array}{l}\text { MBKM Journal of Vapor } \\
\text { Studies }\end{array}$ & References & No & Yes & varchar & 255 \\
\hline Journal volume and number & $\begin{array}{l}\text { For tracking purposes, a journal is often } \\
\text { numbered by the publisher as if it was } \\
\text { part of a large volume. Thus, the issues } \\
\text { of a journal published in the same year } \\
\text { are assigned the same volume number. } \\
\text { The separate issues are assigned a } \\
\text { consecutive number. For example, all } 12 \\
\text { issues of NewsMonth published in } 1987 \\
\text { would have the same volume number } \\
\text { and would be numbered } 1 \text { through } 12\end{array}$ & $12(1)$ & References & No & Yes & char & 10 \\
\hline \multirow[t]{2}{*}{ Laboratory abbreviation } & $\begin{array}{l}\text { Acronym of laboratory performing } \\
\text { analyses }\end{array}$ & VAL & $\begin{array}{l}\text { Analysis Method } \\
\text { Description }\end{array}$ & No & Yes & char & 6 \\
\hline & & & Analysis Results & No & Yes & char & 6 \\
\hline
\end{tabular}




\begin{tabular}{|c|c|c|c|c|c|c|c|}
\hline Entity Name & Description & Examples & Table Name & Key Field? & Can be Null? & Type/Lengtl & \\
\hline Laboratory abbreviation & $\begin{array}{l}\text { Acronym of laboratory performing } \\
\text { analyses }\end{array}$ & VAL & Laboratory Description & Yes & No & char & 6 \\
\hline Laboratory name & Name of laboratory performing analyses & Vapor Analysis Laboratory & Laboratory Description & No & No & varchar & 255 \\
\hline Laboratory $Q A$ level & $\begin{array}{l}\text { Measure of the quality assurance of the } \\
\text { laboratory performing the analyses (this } \\
\text { is the company-defined quality } \\
\text { assurance level) }\end{array}$ & 3 & Laboratory Description & No & Yes & char & 5 \\
\hline Laboratory QA level reference & $\begin{array}{l}\text { System-generated code that identifies } \\
\text { the document where the the laboratory } \\
\text { quality assurance level was cited. This } \\
\text { code is internal to the database and } \\
\text { should not be used for other purposes }\end{array}$ & System generated & Laboratory Description & No & Yes & char & 12 \\
\hline Molecular weight & $\begin{array}{l}\text { Sum of the naturally occuring isotopic } \\
\text { atomic weights of all the atoms in a } \\
\text { molecule (units are gram } / \mathrm{mole} \text { ) }\end{array}$ & 27.0 & Chemical Id Description & No & Yes & float & \\
\hline Number of analyses & $\begin{array}{l}\text { Number of analyses performed on one } \\
\text { sample using the same type of primary } \\
\text { instrumentation or primary method (a } \\
\text { sample is defined as a discrete quantity } \\
\text { of material collecled for analysis) (for } \\
\text { example, } 12 \text { analyses using the ion } \\
\text { chromatograph were performed on one } \\
\text { sample) }\end{array}$ & 12 & Analysis Results & No & Yes & int & \\
\hline Odor & $\begin{array}{l}\text { Description of the smell associated with } \\
\text { a chemical }\end{array}$ & $\begin{array}{l}\text { Pungent } \\
\text { Unpleasant }\end{array}$ & Chemical ld Description & No & Yes & varchar & 255 \\
\hline \multirow[t]{3}{*}{ Page number } & $\begin{array}{l}\text { Page number or range of pages where } \\
\text { the information was cited }\end{array}$ & $\begin{array}{l}877 \\
1234-1255\end{array}$ & Analysis Results & No & Yes & char & 15 \\
\hline & & & Laboratory Description & No & Yes & char & 15 \\
\hline & & & $\begin{array}{l}\text { Physical and Chemical } \\
\text { Properties }\end{array}$ & No & Yes & char & 15 \\
\hline
\end{tabular}




\begin{tabular}{|c|c|c|c|c|c|c|c|}
\hline Entity Name & Description & Examples & Table Name & Key Field? & Can be Null? & Type/Length & \\
\hline \multirow[t]{2}{*}{ Parameter abbreviation } & Acronym of regulatory limit parameter & $\begin{array}{l}\text { REL } \\
\text { STEL } \\
\text { PEL }\end{array}$ & Regulator Parameter & Yes & No & char & 15 \\
\hline & & & Regulatory Limits & Yes & No & char & 15 \\
\hline Parameter description & Name of regulatory limit parameter & $\begin{array}{l}\text { Short-term limit } \\
\text { Permissible exposure limit }\end{array}$ & Regulator Parameter & No & No & varchar & 255 \\
\hline Parameter value & Value given for the regulatory parameter & 1.0 & Regulatory Limits & No & No & float & \\
\hline Parameter value units & $\begin{array}{l}\text { Units for the value of the regulatory } \\
\text { parameter }\end{array}$ & ppm & Regulatory Limits & No & No & char & 10 \\
\hline Precipitation & $\begin{array}{l}\text { Amount of precipitation that has fallen in } \\
\text { the past hour (units are millimeters) }\end{array}$ & $2 \mathrm{~mm}$ & $\begin{array}{l}\text { Surface Meteorological } \\
\text { Data }\end{array}$ & No & Yes & float & \\
\hline Pressure & $\begin{array}{l}\text { Atmospheric pressure measured at a } \\
\text { meteorological tower (units are } \\
\text { millibars). The pressure is reported as a } \\
\text { 15-minute average }\end{array}$ & $1014 \mathrm{mb}$ & $\begin{array}{l}\text { Surface Meteorological } \\
\text { Data }\end{array}$ & No & Yes & float & \\
\hline Property type & $\begin{array}{l}\text { A physical or chemical property of a } \\
\text { chemical (a chemical is defined as an } \\
\text { element or a compound, which includes } \\
\text { radionuclides) }\end{array}$ & $\begin{array}{l}\text { Melting point } \\
\text { Odor threshold } \\
\text { Lower flammability limit }\end{array}$ & $\begin{array}{l}\text { Physical and Chemical } \\
\text { Properties }\end{array}$ & Yes & No & varchar & 30 \\
\hline Property units & $\begin{array}{l}\text { Units used to report a physical or } \\
\text { chemical property. }\end{array}$ & $\begin{array}{l}{ }^{\circ} \mathrm{C} \\
\mathrm{ppm}\end{array}$ & $\begin{array}{l}\text { Physical and Chemical } \\
\text { Properties }\end{array}$ & No & No & char & 10 \\
\hline Property value & $\begin{array}{l}\text { Numeric value of a physical or chemical } \\
\text { property of a chemical }\end{array}$ & 2.0 & $\begin{array}{l}\text { Physical and Chemical } \\
\text { Properties }\end{array}$ & No & No & float & \\
\hline Publisher & $\begin{array}{l}\text { Name of company that printed the } \\
\text { reference }\end{array}$ & $\begin{array}{l}\text { Pacific Northwest Laboratory } \\
\text { Seesing \& Grove, Inc. }\end{array}$ & References & No & Yes & varchar & 255 \\
\hline
\end{tabular}




\begin{tabular}{|c|c|c|c|c|c|c|c|}
\hline Entity Name & Description & Examples & Table Name & Key Field? & Can be Null? & Type/Length & \\
\hline Publisher city & $\begin{array}{l}\text { City where the publisher is located. The } \\
\text { actual city should be reported; however, } \\
\text { if this is not supplied, the city where the } \\
\text { publisher's headquarters are located } \\
\text { should be reported }\end{array}$ & $\begin{array}{l}\text { Richland } \\
\text { Washington, D.C. }\end{array}$ & References & No & Yes & varchar & 30 \\
\hline Publisher country & $\begin{array}{l}\text { Name of the country where the document } \\
\text { was printed }\end{array}$ & Switzerland & References & No & Yes & varchar & 30 \\
\hline Publisher state & $\begin{array}{l}\text { Two-letter abbreviation of state where the } \\
\text { publisher is located. The actual state } \\
\text { should be reported; however, if this is not } \\
\text { supplied, the state where the publisher's } \\
\text { headquarters are located should be } \\
\text { reported }\end{array}$ & WA & References & No & Yes & char & 2 \\
\hline \multirow[t]{4}{*}{ Reference id } & $\begin{array}{l}\text { System-generated code used to make } \\
\text { each reference record unique. This code } \\
\text { is internal to the database and should not } \\
\text { be used for tracking documents }\end{array}$ & System generated & Analysis Results & No & No & char & 12 \\
\hline & & & $\begin{array}{l}\text { Physical and Chemical } \\
\text { Properties }\end{array}$ & No & No & char & 12 \\
\hline & & & References & Yes & No & char & 12 \\
\hline & $"$ & & $\begin{array}{l}\text { Sample-Reference } \\
\text { Relation }\end{array}$ & Yes & No & char & 12 \\
\hline Reference title & $\begin{array}{l}\text { Title of the reference as it appears on the } \\
\text { title page. Subtitles are entered after a } \\
\text { colon. If one volume of a set is } \\
\text { referenced, then the volume title and } \\
\text { volume number should be reported as } \\
\text { part of the title }\end{array}$ & $\begin{array}{l}\text { Vapor Studies: Guidelines for } \\
\text { a Changing Environment } \\
\text { Vol. } 5 \text { Risk Communication }\end{array}$ & References & No & No & varchar & 255 \\
\hline Reference type & $\begin{array}{l}\text { Library classification of the reference. } \\
\text { This is included to make finding the } \\
\text { reference easier }\end{array}$ & $\begin{array}{l}\text { Correspondence } \\
\text { Report } \\
\text { Journal }\end{array}$ & References & No & No & char & 20 \\
\hline
\end{tabular}




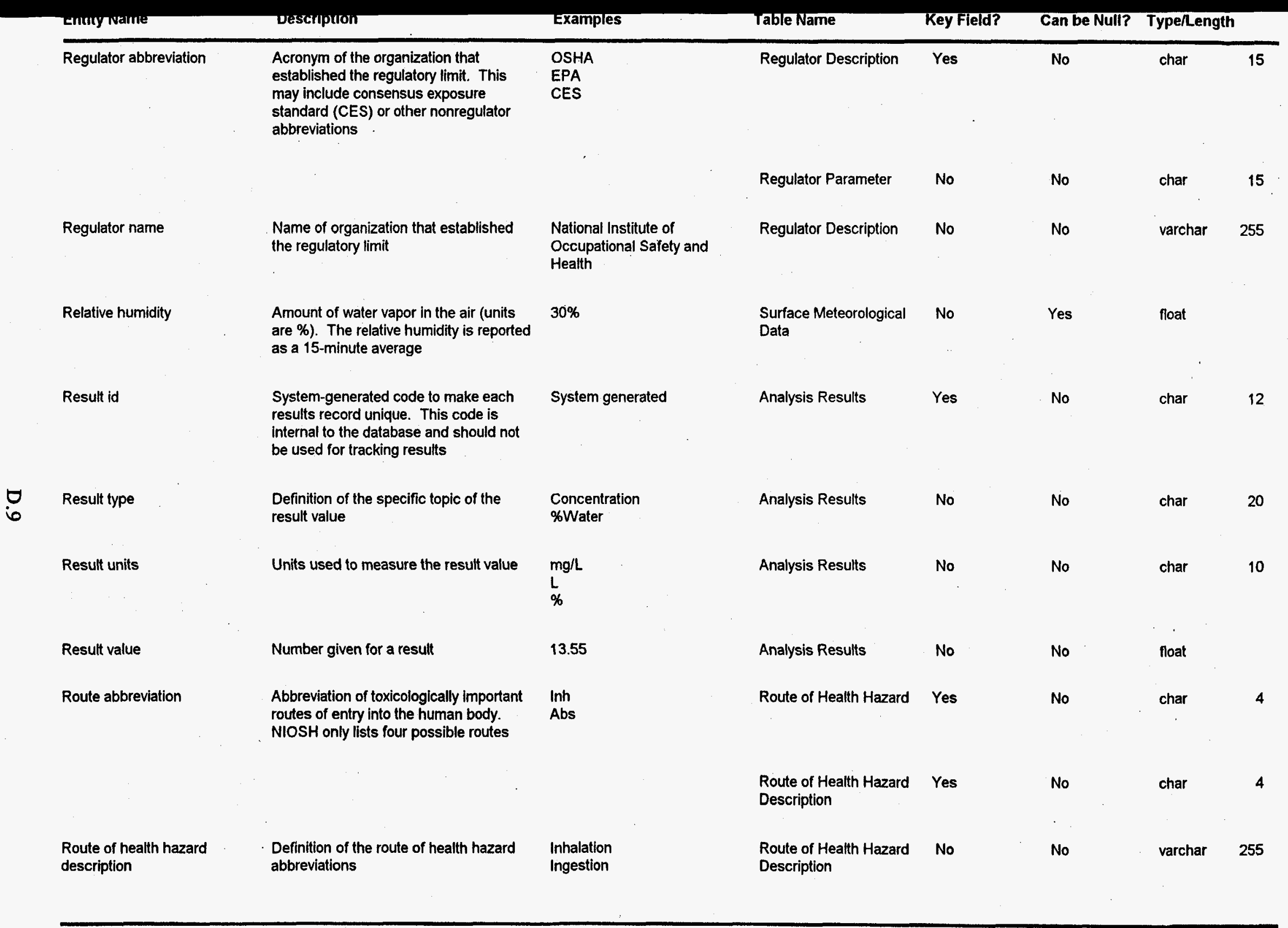




\begin{tabular}{|c|c|c|c|c|c|c|c|}
\hline Entity Name & Description & Examples & Table Name & Key Field? & Can be Null? & Type/Length & \\
\hline Sample id & $\begin{array}{l}\text { Code assigned to a sample by the } \\
\text { collecting organization (a sample is } \\
\text { defined as a discrete quantity of material } \\
\text { collected for analysis) }\end{array}$ & 940811143205 & Sample Data & No & Yes & varchar & 45 \\
\hline Sampling method & $\begin{array}{l}\text { Description of the type of container or } \\
\text { general method used to collect a sample } \\
\text { (a sample is defined as a discrete } \\
\text { quantity of material collected for analysis) }\end{array}$ & $\begin{array}{l}\text { SUMMA canister } \\
\text { OVS tube }\end{array}$ & Sample Data & No & No & char & 20 \\
\hline \multirow[t]{2}{*}{ Scalar wind speed } & $\begin{array}{l}\text { Magnitude of average velocity vector } \\
\text { (units are meter/second). The scalar } \\
\text { wind speed is reported as a 15-minute } \\
\text { average }\end{array}$ & $2.3 \mathrm{~m} / \mathrm{s}$ & $\begin{array}{l}\text { Surface Meteorological } \\
\text { Data }\end{array}$ & No & Yes & float & \\
\hline & & & $\begin{array}{l}\text { Upper Air } \\
\text { Meteorological Data }\end{array}$ & No & Yes & float & \\
\hline Solar radiation & $\begin{array}{l}\text { Amount of direct short-wave } \\
\text { electromagnetic radiation received at a } \\
\text { meteorological tower (units are W/m²). } \\
\text { The solar radiation is reported as a 1- } \\
\text { hour average }\end{array}$ & $75 \mathrm{~W} / \mathrm{m}^{2}$ & $\begin{array}{l}\text { Surface Meteorological } \\
\text { Data }\end{array}$ & No & Yes & float & \\
\hline Std dev of direction & $\begin{array}{l}\text { Amount of variation in wind direction } \\
\text { (units are degrees) }\end{array}$ & $2^{\circ}$ & $\begin{array}{l}\text { Surface Meteorological } \\
\text { Data }\end{array}$ & No & Yes & float & \\
\hline Structure-formula & Structural notation for a chemical & $\mathrm{CH} 3 \mathrm{CHO}$ & Chemical ld Description & No & Yes & varchar & 255 \\
\hline \multirow[t]{2}{*}{ Symptom abbreviation } & $\begin{array}{l}\text { Abbreviation of a potential symptom of } \\
\text { exposure to a chemical }\end{array}$ & $\begin{array}{l}\text { Irrit eyes } \\
\text { Weak } \\
\text { Ftg }\end{array}$ & Symptom Description & Yes & No & char & 15 \\
\hline & & & Symptoms & Yes & No & char & 15 \\
\hline Symptom description & $\begin{array}{l}\text { Description of acute (short term) } \\
\text { symptoms caused by exposure to a } \\
\text { chemical (chronic symptoms are not } \\
\text { included in the database) }\end{array}$ & $\begin{array}{l}\text { Giddiness } \\
\text { Malaise }\end{array}$ & Symptom Description & No & No & varchar & 255 \\
\hline
\end{tabular}




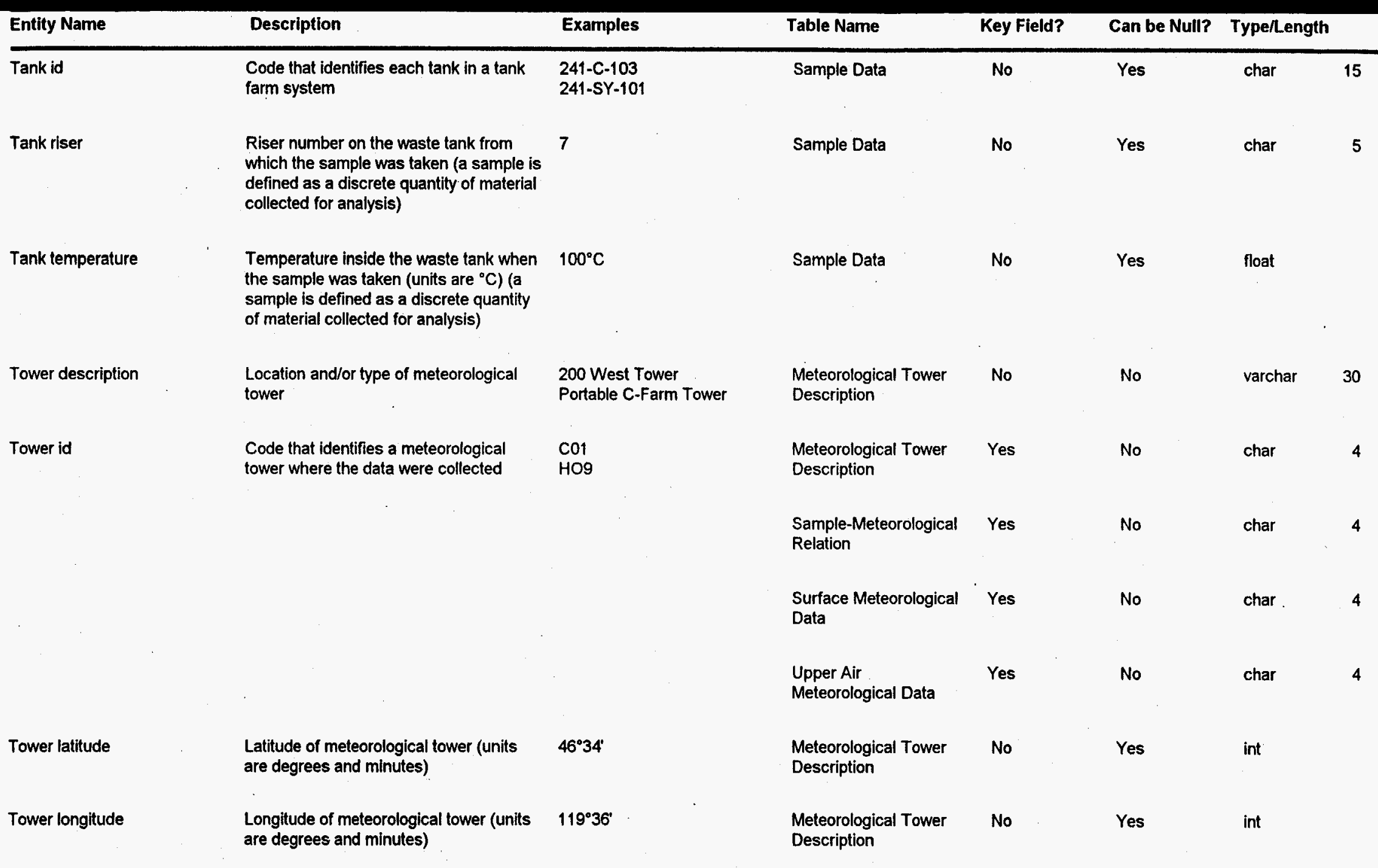




\begin{tabular}{|c|c|c|c|c|c|c|c|}
\hline Entity Name & Description & Examples & Table Name & Key Field? & Can be Null? & Type/Length & \\
\hline Vapor pressure & $\begin{array}{l}\text { Partial pressure of the vapor in } \\
\text { equilibrium over the solid or the liquid } \\
\text { phase }\end{array}$ & 630 & $\begin{array}{l}\text { Vapor Pressure } \\
\text { Property }\end{array}$ & No & No & float & \\
\hline Vector wind speed & $\begin{array}{l}\text { Vector speed of the wind, measuring } \\
\text { both magnitude and direction (units are } \\
\text { meters/second and degrees). The vector } \\
\text { wind speed is reported as a 15-minute } \\
\text { average }\end{array}$ & $5 \mathrm{~m} / \mathrm{s} 240^{\circ}$ & $\begin{array}{l}\text { Surface Meteorological } \\
\text { Data }\end{array}$ & No & Yes & float & \\
\hline Wind direction & $\begin{array}{l}\text { Direction of wind at a specific level on a } \\
\text { meteorological tower (units are degrees) }\end{array}$ & $170^{\circ}$ & $\begin{array}{l}\text { Upper Air } \\
\text { Meteorological Data }\end{array}$ & No & Yes & int & \\
\hline Year published & $\begin{array}{l}\text { Year the reference was published } \\
\text { according to the title page }\end{array}$ & 1994 & References & No & No & char & 4 \\
\hline
\end{tabular}


Appendix E

Component Hardware List for Tank Vapor Database Server 
Description

SUN SS1000 2CPU 64 MB $60 \mathrm{mh}$ or greater

North American power kit

4 × $535 \mathrm{MB}$ system disk space

network interface

Solaris 2.3 Server Media Kit CD

System board/additional for SUN SS1000

64MB memory ECC expansion for SS1000

$6 \times 2.1$ GB GIGARAID disk storage system

Six tape autoloader 4mm DAT tape stacker

Cisco Crescendo FDDI SBus Adapter - Turbo

Cisco WA-C301T SMARTNet

VT420 Monitor

Equipment subtotal

Procurement and other service costs

Total
Units

Cost

$1 \$ 32,050$

1

$\$ 39$

1

$\$ 8,131$

1

$\$ 3,015$

$1 \$ 15,900$

1

$\$ 2,755$

2

$\$ 2,780$

2

$\$ 280$

1

$\$ 365$

$\$ 64,911$

$\$ 4,034$

$\$ 68,944$

E.1 


\section{Distribution}

No. of

Copies

\section{OFFSITE}

2 Office of Scientific and Technical Information

R. A. Jenkins

Oak Ridge National Laboratory

P.O. Box 2009 MS 6120

Oak Ridge, TN 37831

\section{ONSITE}

2 DOE Richland Operations Office
S. O. Branch
R. F. Christensen

S7-54

S7-54

Bechtel Hanford, Inc.

C. M. Jones

S3-90

MACTEC

S. T. Murff

S7-73

4 Westinghouse Hanford Company

E. R. Hewitt

J. L. Huckaby

R. D. Mahan

J. W. Osborne
R3-01

S7-15

S3-90

S7-15
No. of

Copies

27 Pacific Northwest Laboratory

K. J. Allwine

K6-11

W. R. Barchet

R. M. Bean

M. B. Birn (3)

R. W. Bryce

J. S. Fruchter

S. C. Goheen

M. W. Ligotke

D. D. Mahlum

K. L. Manke (3)

P. J. Mellinger

P. R. Seesing (5)

Publishing Coordination

Technical Report Files (5)

\section{Routing}

R. M. Ecker

M. J. Graham

P. M. Irving

R. L. Skaggs

S. A. Rawson

P. C. Hays (last)
K6-11

P8-08

K6-11

K6-96

K6-96

P8-08

P7-82

P7-56

K6-86

P7-22

K6-96

K1-06 